\title{
Estimasi Kesehatan Ekosistem Pertanian Padi Organik Vs Anorganik Berdasarakan Kelimpahan dan Kekayaan Flora, Fauna, Predator dan Layanan Ekosistem
}

\author{
Hanin Niswatul Fauziah \\ Institut Agama Islam Negeri Ponorogo, JawaTimur, Indonesia \\ haninhusein@gmail.com
}

\begin{abstract}
ABSTRAK
Tujuan jurnal review ini adalah untuk mendiskusikan kesehatan ekosistem berdasarkan kelimpahan dan kekayaan flora, fauna, predator dan layanan ekosistem di pertanian organik dan anorganik. Studi yang dilakukan oleh Deb menunjukkan bahwa diversitas flora di plot pertanian padi organik lebih tinggi dibandingkan dengan plot pertanian padi anorganik. Hasil meta analisis menunjukkan bahwa 96 dari 117 studi yang telah dilakukan kelimpahan spesies di pertanian organik 50\% lebih tinggi dibandingkan dengan pertanian anorganik. Diversitas artropoda di plot pertanianan organik lebih rendah dibandingkan dengan plot pertanian organik. Kekayaan burung predator pada pertanian organic lebih tinggi dibandingkan dengan pertanian anorganik. Hal ini karena di pertanian organik memiliki tanaman liar yang digunakan sebagai tempat bertengger, mendapatkan makanan, dan berkembang biak burung predator. Praktek pertanian organik dapat meningkatkan agen biologi kontrol, dalam kasus ini untuk memeliharan musuh alami melalui manipulasi habitat
\end{abstract}

Kata kunci: Flora, Faona, Layanan Ekosistem, Pertanian Organik.

\begin{abstract}
The aims of this review journal were to discuss ecosystem health based on the abundance and richness of flora, fauna, predators and ecosystem services in organic and inorganic rice farming. Deb study showed that flora diversity in organic farming plots was higher than in inorganic farming plots. The results of meta-analysis show that 96 of 117 studies conducted, species abundance in organic farming were 50\% higher than in inorganic farming. Arthropods diversity in inorganic farming plots were also lower than in organic farming plots. The richness of predatory birds on organic farming was higher than in inorganic farming. It was due to in organic farming has a wild plants that were used to perch, get some food and habitat to breed of predatory birds. The practice of organic farming has increased the biological control agent, in this case was the maintenance of natural enemies through habitat manipulation (refugia).
\end{abstract}

Keywords: Ecosystem Services, Flora, Fauna, Organic Farming. 


\section{PENDAHULUAN}

Beras merupakan tanaman biji-bijian dari famili poaceae, varietas yang pada umumnya ditanam adalah Oryza sativa dan Oryza glaberrima (Kassali etal, 2010).Beras merupakan makanan pokok penduduk Asia seperti Indonesia (Phongtai and Rawdkuen, 2015), Malaysia (Mat and Othman, 2014), Banglades dan Cina (Giaraud, 2013). Lebih dari 90\% beras dunia ditanam dan dikonsumsi oleh penduduk Asia (Kassali etal, 2010). Dari tahunketahun, konsumsi beras di negara Asia semakin meningkat seiring dengan bertambahnya jumlah penduduk (Asian Development Bank, 2013; Rohman etal, 2014). Pada tahun 2008 rata-rata konsumsi beras di Indonesia sekitar $139 \mathrm{~kg} / \mathrm{kapita} / \mathrm{tahun}$ (Widayanti etal, 2014), sementara itu konsumsi beras di Asia Tenggara pada tahun 2007-2009 mencapai 1,255 kkal/kapita/hari. Konsumsi beras tahun tersebut meningkat jika dibandingkan dengan konsumsi tahun 1990-1992 yang membutuhkan 1,176 kkal/kapita/hari (Asian Development Program, 2013). Peningkatan konsumsi beras tersebut mendorong pemerintah di negara-negara Asia untuk berupaya meningkatkan produksi beras.

Salah satu upaya pemerintah di negara Asia untuk meningkatkan produksi beras adalah melalui revolusi hijau. Revolusi hijau merupakan program pemerintah untuk meningkatkan produksi pangan (Otsuka dan Yamano, 2005; Sebby, 2010) yang diterapkan melalui intensifikasi dan ekstensifikasi pertanian. Ekstensifikasi pertanian merupakan usaha untuk meningkatkan hasil pertanian melalui perluasan area pertanian yang sebelumnya belum dimanfaatkan oleh manusia, misalnya hutan dan lahan gambut. Sedangkan intensifikasi pertanian merupakan usaha untuk meningkatkan hasil pertanian dengan cara mengoptimalkan lahan pertanian yang sudah ada melalui panca usaha tani. Panca usaha tani meliputi pengolahan tanah yang baik, pengaturan irigasi, penggunaan bibit unggul, pemupukan dan pemberantasan hama (Mariyono et all, 2010).

Revolusi hijau yang terjadi di Indonesia dan negara berkembang lainnya telah mengubah sistem pertanian tradisional (organik) menjadi sistem pertanian konvensional (anorganik). Pertanian organik adalah sistem pertanian yang menggunakan sumber alami dan melarang penggunaan pupuk dan pestisida kimia sintetik (Vogl et al, 2005), sementara pertanian anorganik adalah sistem pertanian yang mengizinkan penggunaan pupuk dan pestisida kimia sintetik. Revolusi hijau ini 
juga telah mengubah paradigma berfikir petani, yang menganggap bahwa peningkatan produksi pertanian hanya dapat dicapai melalui penggunaan pupuk dan pestisida kimia sintetik (Sudjana, tanpa tahun).

Di satu sisi revolusi hijau telah berhasil meningkatkan produksi pangan dan meciptakan negara swasembada pangan, namun di sisi lain revolusi hijau telah memberikan dampak buruk bagi lingkungan akibat penggunaan pupuk dan pestisida kimia buatan. Dampak buruk tersebut seperti meledaknya hama sekunder, hilangnya musuh alami (Mariyono et al, 2010), berkurang bahkan hilangnya biodiversitas, meningkatnya erosi tanah, pencemaran perairandan rusaknya kesehatan ekosistem (Badgley et al, 2006; Ponce et al, 2011), sertaresidunya mencemari beras (Sutrisno dkk, 2009; Zazouli etal, 2010), ASI (Campoy etal., 2001; Minh et al., 2004; Devanathan, 2009; Rahman, 2010; Tutu et al., 2011; Zeinab et al., 2011) dan Darah (Kusuma, 2009). Melihat dampak buruk revolusi hijau terhadap ekosistem pertanian maka perlu ada perbaikan ekosistem pertanian melalui pertanian yang berkelanjutan yaitu dengan cara mengubahsistem pertanian anorganik menjadi pertanian organik.Perubahan sistem pertanian tersebut diharapkan dapat mengembalikan kesehatan ekosistem pertanian.

Berbagai penelitian menunjukkan bahwa pertanian organik dapat meningkatkan biodiversitas organisme pada lahan pertanian, ditunjukkan dalam penelitian (kurnia, 2008) menyatakan bahwa pertanian organik meningktkan kelimpahan oragnisme yang ada pada lahan pertanian serta cenderung lebih ramah terhadap lingkungan. sehingga dapat disimpulkan bahwa ekosistem pertanian organik lebih sehat dan lebih ramah terhadap lingkungan dibandingkan dengan ekosistem pertanian anorganik (Bengtsson et al, 2005). Pertanian organik merupakanpertanian yang berwawasan lingkungankarena ikut memlihara keseimbangan lingkungan melalui ekosistem yang sehat danmemberikan keuntungan pada pembangunanpertanian (Mayrowani, 2012). Ekosistem yang sehat merupakan ekosistem yang berada pada kondisi yang seimbang, mampu mengahasilkan sumberdaya dan memelihara aliran nutrisi yang dibutuhkan, serta mempu menghadapi dan memiliki daya pulih terhadap tekanan dari luar (Costanza dan Mageau, 1999).

Estimasi kesehatan suatu ekosistem dapat dilihat dari berbagai parameter diantaranya adalah kekayaan dan kelimpahan flora, fauna, predator dan layanan 
ekosistem. Oleh karena itu, tujuan jurnal review ini adalah membahas kesehatan ekosistem berdasarkan kelimpahan dan kekayaan flora, fauna, predator dan layanan ekosistem. Sehingga, dari pembahasan ini akan tampak jelas perbedaan kesehatan ekosistem antara pertanian organik dan anorganik.

\section{METODE PENELITIAN}

Penelitian ini termasuk dikategorikan dalam penelitian diskriptif dengan melakukan jurnal review melalui studi pustaka, yaitu dngan cara mengumpulkan datadata terkait dari jurnal-jurnal penelitian yang mengkaji tentang masalah kesehatan dan layanan ekosistem pada pertanian organik maupun anorganik dan selanjutnya dilakukan analisis mendalam terkait temuan data-data yang terdapat pada jurnal tersebut.

\section{HASIL DAN PEMBAHASAN}

Kelimpahan Dan Kekayaan Flora, Fauna dan Predator di Pertanian Organik Dibandingkan dengan Pertanian Anorganik

Salah satu parameter yang dapat digunakan untuk mengukur kesehatan ekosistem adalah diversitas flora. Hasil penelitain Deb (2009) yang menggunakan plot 2x2 m menunjukkan bahwa diversitas flora pada plot pertanian organik lebih tinggi jika dibandingkan dengan plot pertanian anorganik. Di tepi plot percobaanpertanian organik tersebutditanam Cajanus cajan, Phaseolus mungo and Calotropis procera, kemudiandisekitar tanaman tersebut tumbuh beberapa tumbuhan dan herba liar seperti Cyperus rotundus, Bacopa monnieri, Chenopodium album, Marsilea minuta, Aeschynomene indica and Ludwigia parviflora dengan frekuensi lebih dari $70 \%$.Tanaman liar pada sawah tersebut berfungsi sebagai penyedia makanan, habitat untuk berkembang biak beberapa artropoda dan sebagai tempat bertengger burung pemakan serangga.

Hasil penelitian Deb (2009) tersebut senada dengan meta analisis yang dilakukan oleh Bengstsson et al (2005) yang menunjukkan bahwa kelimpahan tanaman liar pada pertanian organik lebih tinggi jika dibandingkan dengan pertanian anorganik. Hasil meta analisistersebutmenunjukkanbahwa 96 dari 117 penelitian yang dilakukan, kelimpahan spesies pada pertanian organik 50\% lebih tinggi jika 
dibandingkan dengan pertanian anorganik. Sementara itu, diversitas tumbuhan liar di plot pertanian anorganik lebih rendah jika dibandingkan dengan plot pertanian organik. Tidak ada tumbuhan liar yang tumbuh disekitar plot pertanian anorganik. Diversitas tumbuhan liar yang ada di sekitar plot pertanian anorganik lebih rendah karena disiangi dan aplikasi herbisida dengan bahan aktif glyphosate (Roundup). Tanaman liar tersebut dihilangkan karena petani menganggap bahwa tanaman liar tersebut dapat menganggu proses pertumbuhan padi (Deb, 2009).

Diversitas Artropoda di plot pertanian anorganik juga lebih rendah jika dibandingkan dengan plot pertanian organik, hal ini karena berkurangnya diversitas tanaman liar yang dapat digunakan sebagai mikrohabitat artropoda. Walaupun pada penelitian ini tidak mempelajari dampak penggunaan herbisida (roundup) pada beberapa hewan namun pada plot pertanian anorganik ditemukan katak dan beberapa insekta mati. Kematian hewan tersebut diduga karena aplikasi herbisida (roundup) pada plot pertanian anorganik (Deb, 2009). Berbagai penelitian menunjukkan bahwa kelimpahan artropoda pada pertanian organik lebih besar jika dibandingkan dengan pertanian anorganik (Deb, 2009; Bengstsson et al, 2005; Takada et al, 2014).

Penelitian yang dilakukan di Ceko menunjukkan bahwa Coleptera dan Aranea pada pertanian organik lebih tinggi jika dibandingkan dengan pertanian organik. Coleoptera merupakan grup yang paling dominan dengan jumlah 5000 spesimen dari 8400 spesimen yang ditemukan, sementara Aranea dominan kedua dengan total 2000 spesimen. Tingginya kelimpahan artropoda tersebut dipengaruhi oleh sistem pertanian, pemanenan, pembajakan, penggunaan pestisida dan kondisi tanah (Mikula et al, 2010).

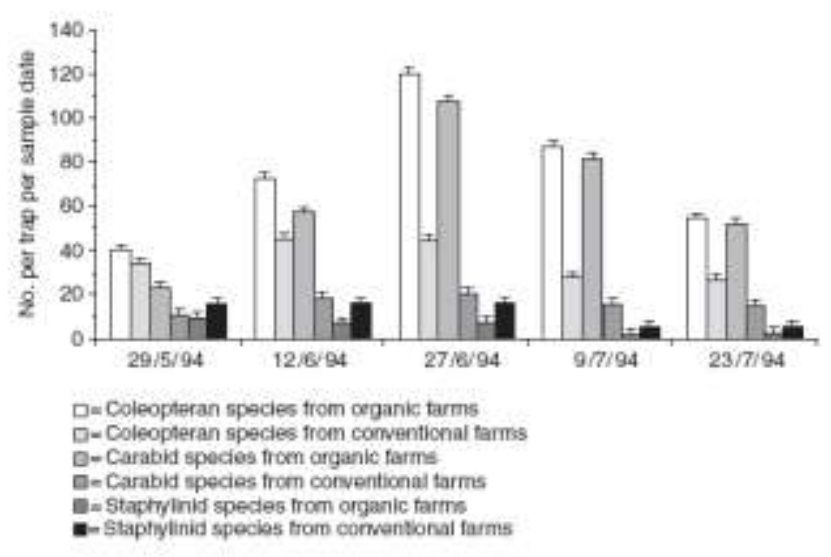

Gambar 1. Rata-rata kelimpahan Coleopteran, Carabid dan Staphylinid pada Pertanian Organik dan Anorganik (Shah et al, 2003). 
Kelimpahan Coleopteran dan Carabid pada pertanian organik lebih tinggi jika dibandingkan dengan pertanian anorganik. Namun kelimpah Staphylinid pada pertanian anorganik 2.3 kali lipat lebih besar jika dibandingkan dengan pertanian organik, namun kelimpahannya menurun secara drastis pada 2 priode akhir pengambilan sampel. Kelimpahan Coleopteran lebih tinggi jika dibandingkan dengan Carabid dan Staphylinid pada pertanian organik, hal ini karena perbedaan tanggal pengambilan sampel dan kelimpahan juga secara signifikan berinteraksi dengan sistem manajemen dan waktu pengambilan sampel dengan kelimpahan terbesar pada akhir Juni (Gambar 1.) Shah et al (2003).

Kelimpahan burung pada plot pertanian organik lebih tinggi dibandingkan pada plot pertanian anorganik (Deb, 2009; Bengstsson et al, 2005; Pfiffner and Luka, 2003). Tingginya kelimpahan burung tersebut diasosiasikan dengan ekoton seperti path pada rumput liar dan tanaman yang ditanam di batas tepi plot seperti Cajanus cajan. Kelimpahan burung pemakan serangga tersebut mengindikasikan ketersediaan prey pada plot pertanian organik. Sehingga dapat dikatakan bahwa tumbuhan liar yang terdapat pada plot pertanian organik tersebut berfungsi sebagai tempat bertengger dan mencari makan burung pemangsa serangga. Burung yang ditemukan pada plot pertanian dan anorganik diantaranya adalah Dicrurus macrocercus, Acridotheres tristis, Merops orientalis, Streptopelia chinensis dan Anastomus oscitans. Rata-rata diveritas burung pada plot pertanian anorganik berkurang selama periode 3 tahun. Berkurangnya diversitas burung pada plot pertanian anorganik karena aplikasi herbisida sehingga mengurangi jumlah serangga yang merupakan makanan burung tersebut (Deb, 2009).

Hasil penelitian menunjukkan bahwa pertanian organik dapat meningkatkan kekayaan spesies tumbuhan liar (Deb, 2009; Bengstsson et al, 2005, artropoda predator dan artropoda non predator (Ponce, 2011). Hasil penelitian dengan menggunakan meta analisis menunjukkan bahwa, rata-rata kekayaanspesiespadapertanianorganik $30 \%$ lebih tinggi dibandingkan dengan pertanianan organik (Bengstsson et al, 2005; Tuck et al, 2014). Ketika semua penelitian dengan data kualitatif dimasukkan dalam estimasi, 53 dari 68 penelitian (84\%) menunjukkan bahwa kekayaan spesies pertanian organik lebih tinggi jika dibandaingkan dengan pertanian anorganik. Tingginya kekayaan spesies pada 
pertanian organik tersebut karena pengelolaan landskap pertanian secara intensif (Bengstsson et al, 2005).

Predator yang banyak ditemukan pada pertanian organik adalah artropoda (labalaba, semut dan kumbang) dan vertebrata (katak, reptil dan burung) (Deb, 2009). Kekayaan Artropoda predator dari famili Tetragnathidae, Lycosidae, Linyphidae, dan Thomisidae pada pertanian organik lebih tinggi dibandingkandengan pertanian anorganik. Lokasi pertanian organik pada penelitian ini berdekatan dengan pertanian anorganik. Setelah aplikasi pestisida, kekayaan artropoda pada pertanian organik menurun, walaupun demikian kekayaan artropoda pada pertanian organik tetap lebih tinggi jika dibandingkan dengan kekayaan artropoda pada pertanian anorganik karena artropoda pada pada pertanian anorganik mati semua (Takada, 2014).

Kekayaan burung predator pada pertanian organik lebih tinggi jika dibandingkan dengan pertanian anorganik, hal ini karena pada pertanian organik terdapat tumbuhan liar yang merupakan tempat bertengger, mencari makan dan habitat untuk berkembang biak. Sedangkan pada pertanian anorganik hanya terdapat sedikit tumbuhan liar akibat aplikasi herbisida dan pestisida. Selain itu, aplikasi pestisida selain membunuh hama target juga dapat membunuh hama nontarget termasuk predator yang memakan hama tersebut. Diantara jenis burung predator tersebut Dicrurusmacrocercus, Acridotherestristis, Anthusrufulus, A. grayii, B. ibis, Meropsorientalis, Streptopeliachinensis,Anastomusoscitans (Deb, 2009).

\section{Layanan Kesehatan Ekosistem Pertanian Organik dibandingkan Pertanian Anorganik}

Penggunaan pestisida telah menurunkan diversitas ekosistem pertaian,sehingga para petaniperlukembalikesistempertanian organic. Karena secara umum pertanian organik merupakan sistem pertanian yang mendukung kesehatan ekosistem karena menggunakan input yang berbasis bahan-bahan dari alam. Praktek pertanian organik telah meningkatkan agen pengendali biologi dalam hal ini adalah memaintenance musuh alami melalui manipulasi habitat (refugia) (Deb, 2009). Pada pertanian organik tanaman seperti Cyperus rotundus, Bacopa monnieri, Chenopodium album, Marsilea minuta, Aeschynomene indica dan Ludwigian parviflora yang terdapat pada pematang sawah berfungsi sebagai tempat mencari makan dan breeding habitat bagi beberapa 
arthropoda dan tempat bertengger bagi burung-burung pemakan serangga herbivor. Beberapa literatur menyebutkan bahwa terdapat hubungan antara diversitas predator dan pest. peningkatan diversitas predator dapat menekan laju hama.Pada pertanian organik predator ada pada sepanjang musim tanam dan jumlah predator pertanian mampu menurunkan jumlah hama dan mengurangi kerusakan sehingga akan meningkatkan produksi pertanian. Deb (2009) menyatakan bahwa peningkatan diversitas pada suatu ekosistem akan meningkatkan panjang rantai makanan. Rantai makanan yang terdapat pada pertanian organik lebih panjang dibandingkan dengan pertanian anorganik, sehingga dapat dikatakan bahwa ekosistem di pertanian organik lebih kompleks dibandingkan ekosistem pertanian anorganik.

\section{SIMPULAN}

Berdasarkan jurnal review di atas dapat disimpulkan bahwa kelimpahan dan kekayaan flora, fauna, dan predator di pertanian organic lebih tinggi dibandingkan dengan kekayaan flora, fauna, dan predator di pertanian anorganik. Disamping itu, layanan kesehatan ekosistem di pertanian organic lebih baik dibandingkan dengan layanan kesehatan ekosistem pertanianan organik. Rantai makanan di pertanian organik lebih panjang dibandingkan dengan rantai makanan di pertanianan organik. Sehingga dapat dikatakan bahwa ekosistem di pertanian organik lebih kompleks dibandingkan dengan ekosistem di pertanian anorganik.

\section{DAFTAR PUSTAKA}

Asian Development Program. (2013). Food Security in Asia and The Pacific. Departmen of External Relation. Phillippinea.

Badgley et al. (2006). Organic Agriculture and The Global Food Supply. Renewable Agriculture and Food System. 22(2):86-108.

Bengtsson, J., Ahnstrom, J., Christin, A. (2005). The effects of organic agriculture on biodiversity and abundance: a meta-analysis. Journal of Appied Ecology. 42:261-269.

Campoy C. et al. (2001). Analysis of Organochlorine Pesticides in Human Milk: Preliminaru Result. Early Human Development. 65: 183-190.

Costanza, R and Mageau, M. (1999). What is Healthy Ecosistem?. Aquatic Ecology.33:105-115. 
Deb, D. (2009). Biodiversity and Complexity of Rice Farm Ecosystems: An Empirical Assessment. The Open Ecology Journal 2,112-129.

Devanathan G., Subramanian A., Someya M., Sudaryanto A., Isobe T., Takahasi S., Chakraborty P., dan Tanabe S. (2009). Persistent Organochlorine in Human Breast Milk from Major Metropolitas Cities India. Environmental Pollution 157:148-154.

Giraud, G. (2013). The World Market of Fragrant Rice, Main Issues and Perspective. International Food and Agribusiness Management. 16(2):1-20.

Kassali, R., Kareem R., Oluwasola, O., and Ohaegbulam, O.M. (2010). Analysis of Demand for Rice in Ile Ife, Osun State, Nigeria. Journal of Sustainable Development in Africa. 12(2):63-78.

Kurnia, E.R. (2008). Keaneka Ragaman Antrophoda Pada Lahan Padi Organik dan Anorganik di Desa Bentengan Kabupaten Kediri. Universitas Negeri Malang

Kusuma Z. (2009). Dampak Pencemaran Pestisida di DAS Brantas Hulu. Jurnal agritek 17(3)

Letourneau, D.K., Bothwell S,G. (2008). Comparison of organic and conventional farms: challenging ecologists to make biodiversity functional. Front Ecol Environ. 6(8):430-438.

Man, B. and Othman, B. (2015). Regional Cooperation in Addressing Food Security Issues in Southeast Asia: Malaysaian Perspective. Malaysian Journal of Society and Space. 10(6):37-47.

Mariyono, J., Kompas, T., Grafton, R.Q. (2010). Shifting from Green Revolution to Environmentally Sound Policies: Technological Change in Indonesian Rice Agriculture. Journal of the Asia Pacific Economy. 15(2):128-147.

Mayrowani, H. (2012). The Development of Organic Agriculture in Indonesia.Pusat Sosial Ekonomi dan Kebijakan Pertanian. https://media.neliti.com/media/publications/69780-none-da945e16.pdf.

Mikula, J., Laska, V., Sarapatka, B., Tufova, J. And Tuf, I.H. (2010). Soil Invertebrates in Conventionally and Organically Farmed Fields of Winter Wheat and Winter Oilseed Rape in The Czech Republic. Acta Soc.Zool.Bohem. 74:8589.

Minh N.H., et al. (2004). Persistent Organochlorine Residues in Human Breast Milk from Hanoi and Hochiminh City, Vietnam: Contamination, Accumulation Kinetics and Risk Assessment for Infant. Environmental Pollution. 129. 
Otsuka, K. \& Yamano, T. (2005). The Possibility of a Green Revolution in SubSaharan African: Evidence fro Kenya. Electronic Journal of Aagricultural and Development Economics. 2(1):7-19.

Pfiffner, L. \& Luka, H. (2003). Effect of Low-Input Farming System on Carabids and Epigeal Spiders- a Paired Farm Approach. Basic and Applied Ecology. 4:117127.

Phongtai, S. \& Rawdkuen, S. (2015). Preparation of Rice Bran Protein Isolates Using Three-Phase Partioning and Its Properties. Food and Applies Bioscience Journal. 3(2):137-149.

Ponce, Carlos., Bravo, Carolina., de Leon, David Grarcia., Magana, Marina., Alonso Juan Carlos. (2011). Effect of Organic Farming on Plant and Arthropod Communities: A Case Study in Mediterranea Dryland Cereal. Agriculture, Ecosystem and Environment.141:193-201.

Rahman S.H.A. (2010). Persisitent Organochlorine in Human Breast Milk from AlSharkia Governorate, Egypt. Egypt.Aced.J.biolog.Sci. 2(1):21-30.

Rohman, A., Helmiyati, S., Hapsari, M., dan Setyaningrum, D. L. (2014). Rice in Health and Nutrition. International Food Research Journal.21(1):13-24.

Sebby, K. (2010). The Green Revolution of The 1960'S and Its Impact on Small Farmers in India. Undergraduate Thesis, Environmental Studies Major. University of Nebraska-Lincoln.

Shah, P.A., Brooks D.R., Ashby J.E., Perry, J.N., and Wolwod, L.P. (2003). Diversity and Abundance of The Coleopteran Fauna From Organic and Conventional Management System in Soutern England. Agricultural and Forest Entomology. 5:51-60.

Sudjana, B. tanpa tahun. Pertanian Berkelanjutan Berbasis Kesehatan Tanah dalam Mendukung Ketahanan Pangan.Fakultas Pertanian. Universitas Singaperbangsa Karawang.

Sutrisno, N, Setyanto, P, dan Kurnia U. (2009). Perspektif Dan Urgensi Pengelolaan Lingkungan Pertanian Yang Tepat. Pengembangan Inovasi Pertanian 2(4): 286291.

Takada, M.B., Takagi, S., Iwabuchi, S., Mineta, T., and Washitani, I. (2014). Comparison of Generalist Predator in Winter-Flooded and Conventionally Managed Rice Paddies and Identification of Their Limiting Factors. Springer Plus. 3(1):418-424.

Tuck, S.L., Winqvist, C., Mota, F. And Ahnstrom, J. (2014). Land-Use Intensity and The Effects of Organic Farming on Biodiversity: a Heararchical Meta-Analysis. Journal of Aplied Ecology.51:746-755. 
Tutu A.O., Golow Y.A.A., Denutsui D., and Arthur B.S. (2011). Organochlorine Pesticides Residues in Breast Milk of Some Primiparae Mother in La Community, Accra, Ghana. Research Journal of Envirinmental and Earth Sciences. 3(2):153-159.

Vogl, C.R., Kilcher L, Schmidt, H. (2005). Are Standards and Regulations of Organic Farming Moving Away from Small Farmers' Knowledge. Journal of Sustainable Agriculture. 26(1):5-26.

Widayanti, A., Sunaryo, 1., and Kumalasri, A.D. (2014). Reducing The Dependency on Rice as Staple Food in Indonesia a Behavior Intervention Approach. Jounal ISSAAS. 20(1):93-103.

Zazouli, M.A., Bandpei, A.M., Ebrahimi,M., and Izanloo, H. (2010). Investigation of Cadmium and Lead Content in Iranian Rice Cultivated in Babol Region. Asian Journal of Chemistry. 22(1):1369-1366.

Zeinab Al-Targi H.M., Refaat, Ela G.A.E. and El-Dressi A.Y. (2011). Organochlorine Pesticide Residues in Human Milk in El-Gabal Al-Akhdar, Libya. IPCBEE. 3. 